Open Access

\title{
Leishmaniases diagnosis: an update on the use of immunological and molecular tools
}

\author{
Milena de Paiva-Cavalcanti ${ }^{1 *}$, Rayana Carla Silva de Morais ${ }^{1}$, Rômulo Pessoa-e-Silva', \\ Lays Adrianne Mendonça Trajano-Silva', Suênia da Cunha Gonçalves-de-Albuquerque?', \\ Diego de Hollanda Cavalcanti Tavares ${ }^{1}$, Maria Carolina Accioly Brelaz-de-Castro ${ }^{1}$, Rafael de Freitas e Silva ${ }^{1,2}$ \\ and Valéria Rêgo Alves Pereira ${ }^{1}$
}

\begin{abstract}
Leishmaniases are caused by obligate intracellular protozoan parasites of the genus Leishmania. They cause a spectrum of diseases, most notably visceral (VL), cutaneous (CL), and mucosal (ML) leishmaniasis, which affect millions of people around the world, each year. Despite scientific advances, leishmaniases cases are expanding, constituting an important public health problem. Immunological and molecular diagnostic tools have been increasingly applied for the early detection of these parasitic infections, since the existence of limitations in clinical and parasitological examinations may provide false results, thus interfering in epidemiological research and diseases control. Although there is a great diversity of available immunological assays, important common deficiencies persist, which explains the current exploration of the molecular biology in research fields, especially the Polymerase Chain Reaction (PCR) and its variants, such as real-time quantitative PCR. However, in the last years, significant results have also been reached inside of immunological context (especially by Flow Cytometry), for humans and dogs, demonstrated by research works of the New and Old worlds. In spite of their potential to clarify and minimize the present global situation of the diseases, the implementation of molecular or immunological innovative reference assays for $\mathrm{VL}$ and $\mathrm{CL}$ at health services is still a challenge due to several reasons, including lack of standardization among laboratories and structural concerns. In this article we bring classical and current information about technological advances for the immunological and molecular leishmaniases diagnosis, their features, and applications.
\end{abstract}

Keywords: Visceral leishmaniasis, Cutaneous leishmaniasis, Diagnosis, Immunological tools, Molecular tools

\section{Introduction}

Leishmaniases are caused by obligate intracellular protozoan parasites of the genus Leishmania, capable of developing a spectrum of diseases, most notably visceral $(\mathrm{VL})$, cutaneous $(\mathrm{CL})$, and mucosal (ML) leishmaniasis [1, 2]. Global VL and CL incidences are approximately 0.2-0.4 million and 0.7-1.2 million cases occurring each year, respectively [3]. Despite the increasing number of infected individuals being registered in several countries of the Americas (New world) Europe, Asia and Africa (Old world), a huge number of cases are believed to be under-reported [4].

\footnotetext{
* Correspondence: mp@cpqam.fiocruz.br

${ }^{1}$ Department of Immunology, Aggeu Magalhães Research Center, Oswaldo Cruz Foundation, Av. Prof. Moraes Rego s / n, 50670-420 Recife, PE, Brazil Full list of author information is available at the end of the article
}

Leishmaniases are still ignored in discussions of tropical disease priorities, even being estimated to cause the ninth largest disease burden among individual infectious diseases [5, 6]. Despite scientific advances, leishmaniases constitute an important public health problem. Up to the moment, the leishmaniases diagnosis is performed by an association of clinical, epidemiological and laboratorial data. Particularly in relation to laboratorial methods, the lack of a gold-standard for human patients or animals is a limitation for the disease control, because the achievement of accurate epidemiological data is associated with the guidance of control measures, thus helping to increase their efficiency. Furthermore, false-negative results could delay early implementation of treatment, thereby contributing for maintenance of reservoirs, and as a consequence, the preservation of parasitological cycles in their environment. 
Rapid methods for diagnosis and species identification are urgently needed, along with therapies, prophylactics, and control measures that are effective, safe, affordable, and easily administered [2]. In this context, this article provides an overview on classical diagnosis and current information about technological advances for the immunological and molecular leishmaniases diagnosis, their features, applications, limitations and perspectives.

\section{Immunological tools for visceral and cutaneous leishmaniasis diagnosis}

The immunological procedures have been employed for screening and for the definitive diagnosis of diverse parasitological illnesses because of their easiness and accuracy. For leishmaniases, these methods are largely applied, being, in some routine protocols, the single diagnostic principle, before anti-Leishmania drug prescription [7]. Nonetheless, important limitations may carry to incorrect diagnostic interpretation, like cross-reactions, especially with phylogenetically closely related species, and loss of accuracy in immunosuppressed patients. The combination of different techniques, like immunochromatographic test (ICT) and rapid immunoenzyme assay, or the employment of different antigenic targets and the combination of distinct recombinant proteins in the same assay are strategies that may improve the global specificity and sensitivity, thus bringing a higher accuracy to the routine protocols $[8-10]$. The association with the molecular biology, mainly in reference centers, has become a common approach to the differential diagnosis of leishmaniases, especially when parasitology is also inconclusive $[11,12]$. Even so, researchers around the world have been developing new protocols and technologies to the continuous enhancement of the immunological diagnosis, thus ensuring smaller risks to patients in the detection of leishmaniases.

\section{Classical immunological tools}

Montenegro skin test (MST) has been successfully used in the diagnosis of cutaneous forms, but is negative for recent lesions, in the diffuse form, and also in immunosuppressed patients [13]. The test is commonly positive in endemic areas due to the occurrence of subclinical infections. Furthermore, other characteristics may hamper the applicability of the method: cross-reactions; long time to retest, if necessary (at least two years); falsepositive results caused by lack of patient cooperation, which itches the application site; subjectivity of the reading (especially when the diameter of the induration has between 4 and $5 \mathrm{~mm}$ ) and so on [14]. In the diagnosis of $\mathrm{CL}$ the use of indirect immunofluorescence assay (IFA) associated with MST or a parasitological technique is recommended to provide a differential diagnosis. The limitation of IFA lies in the fact that it does not correlate the levels of circulating antibodies with disease staging. In addition, there is the possibility of cross reactivity with other trypanosomatids and fungi [15-17]. IFA is based on the detection of anti-leishmania antibodies by employing specific antigens (promastigote form, normally) and secondary antibodies (anti-immunoglobulin antibody) conjugated with a fluorescent dye [16, 17]. The technique is becoming less explored in routine not only for CL diagnosis, but also for canine VL (CVL) diagnosis mainly because of its low specificity, in contrast with the high sensitivity. Incompatibility or poor reaction between the secondary and primary antibodies or the antigen are also constraints associated with this indirect immunological assay.

The majority of the immunological techniques for detection of anti-Leishmania antibodies has been based on reactions like Enzyme-Linked Immunosorbent Assay (ELISA) [11, 18]. The sensitivity and specificity of ELISA depends on the antigen used [11]. In this context, several antigens with different molecular weights have been identified for potential use in the diagnosis. Recombinant Leishmania protein K39 (rK39), a very important and broadly employed antigen, showed $100 \%$ specificity and $96 \%$ sensitivity for the diagnosis of VL [19]. An interesting feature of this antigen is that it can be used in patients co-infected with HIV, in which anti-K39 antibody levels decline rapidly with the treatment success $[11,20,21]$. Other candidates for the diagnosis of several forms of leishmaniases are recombinant or purified membrane glycoproteins (gp): gp63, gp70, and gp72, and A2 protein, all of which are specific for the genus Leishmania. A2 protein is present in amastigotes, and studies suggest that is particularly useful for diagnosis of canine VL $[20,21]$. The use of recombinant or purified gp63, gp72 or gp70 improved the sensitivity and specificity of ELISA. However, cross-reactions with other diseases caused by trypanosomes may occur [22, 23].

The numerous commercial kits of rapid diagnostic tests (RDTs) available are largely explored nowadays in routine. The easiness concerning its use and interpretation, as well as the quick results have contributed to its broad application, especially for screening. The high stability in a broad range of temperature (generally $4-30{ }^{\circ} \mathrm{C}$ ) facilitates its employment in field for screening of CVL. RDTs are based on the detection of specific antibodies in serum or peripheral blood of the patient with VL. An important RDT, known as TRALd (Rapid Antibody Test Leishmania donovani) was developed using two recombinant proteins, the rK39 and K26, fixed on nitrocellulose paper. An initial clinical evaluation of TRALd observed $100 \%$ of sensitivity and $98 \%$ of specificity [11, 21, 23, 24]. Even when antigenic combinations are used, there is the possibility of cross-reactions with other trypanosomatids, being then indicated the application of a confirmatory 
exam, normally of a distinct principle (e.g. IFA, ELISA etc.) or distinct antigenic composition.

\section{New immunological tools}

In relation to the new immunological tools, the use of flow cytometry $(\mathrm{FC})$ in the diagnosis of canine VL through the detection of anti-fixed L. infantum antibodies has been increasingly explored [25]. Researchers demonstrated an excellent performance of an FC prototype in canine VL diagnostic, with high specificity, sensitivity, predictive values and accuracy, even when animals were infected with other pathogens (such as Trypanosoma cruzi and $\mathrm{Ba}$ besia canis), and also absence of false-positive results in vaccinated dogs [26]. Recently it was demonstrated the potential of a magnetic microsphere coated with Leishmania recombinant antigens associated with FC as a viable tool for a highly sensitive laboratorial serodiagnosis of both clinical and subclinical forms of canine disease [27]. For human form, it was shown the detection of specific IgG antibodies against $L$. chagasi using FC for cure assessment [28].

FC to detect anti-live L. braziliensis antibodies has been first described by Rocha et al. [29], in which they demonstrated $93.6 \%$ sensitivity in patients with active disease. Researchers working with live and fixed $L$. braziliensis showed that FC can be a useful serological technique to detect anti- L. braziliensis IgG antibodies, with the antigens displaying an 86 and $90 \%$ sensitivity, respectively [30]. A good performance using fixed $L$. amazonensis promastigotes was also demonstrated [31]. Oliveira et al. [32] showed that FC had a better performance compared to IFA in the monitoring of specific post therapeutic cure of CL. Therefore, FC is becoming an increasingly useful tool in health care and research laboratories, due to its accuracy and reproducibility. Although there is still a substantial cost regarding the operational support in experiments involving FC, Shared Resource Laboratory models are enhancing the scope and quality of scientific research that applies the FC based methodologies [26, 33, 34].

The Table 1 summarizes the main aspects addressed in the immunological methods used in leishmaniases diagnosis.

\section{Molecular tools for leishmaniases diagnosis}

The limitations demonstrated by the conventional techniques, both parasitological and serological, have led the scientists to an increasing exploration of the molecular biology as a complement, as well as an alternative for the accurate diagnosis of leishmaniases. The practicality, safety and reliability of the molecular tools, in addition to the wide number of applications and the promising results have contributed to the continuous acceptance of these methods in routine and reference laboratories around the world.

The Polymerase Chain Reaction (PCR) technique and its variations, like Nested-PCR (nPCR), Seminested-PCR (snPCR) and Quantitative Real Time PCR (qPCR) have been largely employed for the optimization of new diagnostic assays, using different target regions and samples [35-37]. The follow-up of the treatment aiming the evaluation of a drug efficacy is a common approach [38] proportionated by the $\mathrm{qPCR}$, with its capacity to estimate the parasitological burden in several specimen types [39,

Table 1 Advantages and limitations of immunological methods used in leishmaniases diagnosis

\begin{tabular}{lll}
\hline Method & Antigen & Advantage \\
\hline Montenegro skin test & Killed whole parasites & $\begin{array}{l}\text { Low cost and detection of T cell } \\
\text { immunity }\end{array}$ \\
& & \\
& & \\
$\begin{array}{l}\text { Enzyme-Linked Immunoabsorbent } \\
\text { Assay (ELISA) }\end{array}$ & Recombinant molecules & $\begin{array}{l}\text { Low cost and high sensitivity and } \\
\text { Immunofluorescence }\end{array}$ \\
& Killed whole parasites & High sensitivity and specificity
\end{tabular}

Flow cytometry

Rapid Antibody Test (RAT)

Direct Agglutination Test (DAT)
Recombinant molecules and/ or killed whole parasites have been tested

Recombinant molecules

Killed whole parasites
Better sensitivity and specificity when compared with all other methods. Small amount of blood. Can differentiate between infection and disease, and cured patients.

Low cost, small amount of blood, fast

Low cost, small amount of blood
Limitation

May not detect cases of visceral leishmaniasis in some stages of the disease. Cannot differentiate between infection and disease, nor active and progressive disease. Risk of recurrence.

Sensitivity and specificity is highly dependent on the antigen used

Laborious process, time and cost consuming. Need of trained personnel to perform the test.

Cost associated with reagents and equipment. Few studies yet.

Sensitivity and specificity is highly dependent on the antigen used

Need of long incubation time, well-trained laboratory technicians, antigen cost, and quality controlled antigen 
40]. Species characterization of Leishmania is also an important application of the PCR, and it has been strongly explored nowadays [41, 42]. Coupled with different methodologies, including gene sequencing and Restriction Fragment Length Polymorphism (RFLP) analysis, the studies have brought this kind of analysis with distinct goals: species confirmation in epidemiological researches [43, 44], specificity assessment of new optimized assays $[11,45]$ and comparative studies [46], for example. Ozensoy-Toz et al. [47] have used fluorescent dyes and the resulting melting temperature $(\mathrm{Tm})$ interpretation as criterion for Leishmania species differentiation, to both $\mathrm{CL}$ and VL etiological agents, with success. The author, as others $[43,48]$, also performed phylogenetic analysis of species from isolates by gene amplification and sequencing. According to Grimaldi and Tesh [49], the correct identification of the causative Leishmania species is directly related to decision upon the appropriate treatment regimens and to design effective control programs.

\section{Visceral leishmaniasis diagnosis}

Between 2011 and 2013, conventional PCR protocols for VL presented a sensitivity variation from 53.7 to $97.78 \%$ for humans and from 72.2 to $98.7 \%$ for dogs, and the specificity varied from 61.82 to $100 \%$ for humans and from 83.3 to $96.4 \%$ for dogs $[41,43,50,51]$. The high variability also occurs to qPCR for humans, with a specificity variation from 29.6 to $100 \%$. The range of sensitivity $(91.3-100 \%)[41,51]$ presented short and with high values, thus demonstrating the applicability of the qPCR at situations in which a sensitive tool is pivotal, like disease monitoring to predict relapse. Results obtained by Solcà et al. [52] show the PCR as being more sensitive than $\mathrm{qPCR}$ in dog samples. This reinforces that some characteristics like the DNA target region, as well as the pair of primers used may be determinant.

As occurs in different clinical statuses, the parasitic burden in the various samples differs. Getting advantage on the specimen type, Pandey et al. [53] and Silva et al. [54] standardized PCR reactions (snPCR and qPCR, respectively) to detect the parasite DNA from Giemsastained smears, prepared from bone marrow aspirates. The first author's assay detected $L$. donovani DNA in $68.7 \%$ of the human samples. The second author detected L. chagasi DNA in $100 \%$ of the canine samples. Both assays presented superiority in relation to microscopy and culture. Other alternative samples, like urine and conjunctival swabs are being largely explored for humans $[55,56]$ and dogs $[39,57-60]$ with good accuracy. Although the small parasite DNA amount, they do not request invasive procedures for obtaining, thus bringing security and comfort to the patient $[36,57]$.

Despite these advantages, several Taq Polymerase inhibitors are found in these clinical specimens or they are commonly used for sample collection and DNA extraction, like EDTA, Proteinase $\mathrm{K}$, Phenol and high salts concentrations [61, 62]. Recently, some authors have brought the strategy of the multiplex PCR to include endogenous controls altogether with the detection system of Leishmania sp., in the same reaction, for PCR [61] and qPCR [63] assays. Mohammadiha et al. [41] performed this multiplex format for humans and dogs, using TaqMan-based qPCR, having reached a very good sensitivity in both cases (93.9-100\%, respectively). Gonçalves-de-Albuquerque et al. [64] standardized a triplex PCR to CL capable to monitor not only the sample quality, but also small losses of DNA during the extraction process by using a plasmid as reporter.

Innovative molecular approaches, as the Nucleic Acid Sequence-Based Assay (NASBA), the Loop-Mediated Isothermal Amplification (LAMP), and the low-tech OligoTesT have been increasingly applied for Leishmania DNA or RNA detection. The NASBA have its variations, the quantitative (QT-NASBA) and coupled to oligochromatography (NASBA-OC) [65-69]. Vries et al. [65] have used QT-NASBA for the evaluation of the efficacy of a drug for VL treatment, by estimating the quantification of $L$. infantum parasites in blood. Basiye et al. [66] and Mugasa et al. [67] have applied NASBA-OC to diagnostic assays development, based on L. donovani RNA detection, reaching sensitivity of 79.80-93.30\% (respectively) and specificity of $100 \%$ (both). The NASBA-OC uses a sensitized membrane of an oligochromatographic dipstick to detect the amplified RNA, in 5-10 min just with a pipette and a water bath, but without quantification capacity [68]. QTNASBA has the inconvenience of the electrochemiluminescence as tool of detection, which involves more handling steps and procedure time than qPCR and Reverse transcription-qPCR (RT-qPCR) [69].

The LAMP, a promising diagnostic tool, has been adopted as an alternative technique to PCR, since it is a faster, sensitive and less expensive technology, which uses the turbidity of the sample as criteria of positivity. There is no need of a thermal cycler, just a water bath or a heat block, since the reaction is isothermal. Therefore, this is a tool suitable for field application [70, 71]. Verma et al. [72] developed a LAMP-based assay for $L$. donovani detection in humans with VL and Post-Kala-azar Dermal Leishmaniasis (PKDL) in which the sensitivity and specificity rates were good to both cases, achieving 96.4-98.5 \% (in VL blood samples); 96.8-98.5 \% (in tissue biopsy samples). Nevertheless, Chaouch et al. [73] developed a LAMP amplification for L. infantum detection in dogs, and the sensitivity reached was low (54.2\%), though having performed better than IF and PCR, statistically. The chosen target (cysteine Protease B gene - cpb) and the non-use of an internal quality control can in part explain this result. 


\section{Cutaneous leishmaniasis diagnosis}

As presented for VL, molecular techniques are advancing in studies for increasing their sensibility and specificity. They have been increasingly recommended for CL diagnosis due to their accuracy and speed [74], when compared to conventional diagnostic methods [47, 74]. Mohaghegh et al. [75] used PCR for confirming negative direct stained smear, confirming the higher sensitivity of the molecular method in comparison with classical diagnosis (direct stained smear). As for VL, different biological samples can be used with the molecular technology: blood [76], smear [75], scarification of the edge lesion [77] and biopsy skin [78, 79].

Several authors have used the qPCR technology to detect the DNA from the etiological agents in varied samples from animals and human patients, allowing studies related to parasite load, host-parasite interaction, monitoring of therapy and post-treatment response in infected human patients $[80,81]$. Another common approach to CL is the application for differentiation of Leishmania species [47, 81-83]. Authors using dyes or fluorescent probes have had great results. Paiva-Cavalcanti et al. [82] used skin samples from humans and blood samples from domestic animals; Ozensoy Toz et al. [47] used skin aspiration fluid, smear, and biopsy from human patients; Pita-Pereira et al. [83] used skin biopsy samples from patients living in areas with well-known occurrences of CL. They have differentiated Viannia and Leishmania subgenera through Tm. Nonetheless, the qPCR requires a laboratory with the technical capacity to perform it; thus, this technology is becoming available at Central Diagnostic Laboratories, in countries where leishmaniases are endemic [81].

The nPCR is commonly used for some researchers [78]. Shirian et al. [84] performed the technique by using scraped off of slides with impression smears from 20 suspect cases of ML, getting 18 positive samples (90\%). Only eight were positive through direct microscopy (44.4 \%). The PCR based method was not only a useful and more precise diagnostic approach in the identification of ML cases with negative cytology, but also showed to be efficient in determining the species of the parasites. Azzi et al. [74] concluded that nPCR is a useful technique for studying the molecular epidemiology in the field.

The QT-NASBA assay is a useful instrument to monitor parasite load in skin biopsies of patients with $\mathrm{CL}$ after treatment and can help to predict clinical outcome [69]. qPCR, RT-qPCR and QT-NASBA were compared by Van der Meide et al. [69], and they concluded that RT-qPCR and QT-NASBA are the most sensitive assays, generating reproducible results. However, as described before, QT-NASBA is less convenient since the electrochemiluminescence detection involves more handling steps and procedure time.
Despite the variety of molecular tools (Pulsed Field Gel Electrophoresis - PFGE, the Multilocus Enzyme Electrophoresis - MEE, and more), PCR still represents one of the major advances on diagnosis and research of the leishmaniases [85], even presenting its deficiencies, which have been minimized due to the continuous effort of researchers, attempting to bring more viability to its application in health service.

Table 2 summarizes the main aspects addressed in the molecular methods used in leishmaniases diagnosis.

Table 3 gathers the clinical sensitivities and specificities of the immunological and molecular methods commented throughout the text.

\section{Molecular targets}

Several different genomic targets are used for Leishmania sp. detection as rDNA (ITS-1 and SSU rDNA), kinetoplastid minicircle DNA (kDNA), splice leader miniexon (SMLE), tryparedoxin peroxidase gene and, heatshock protein 70 gene (HSP70) [47, 77, 79, 82, 86-89]. This is one of the challenges to be surpassed for a future implementation of a gold-standard molecular methodology for CL and VL. Nevertheless, the choice of each target is related to the different applicability, i.e., with the objectives of each study, such as the case of HSP70 used by authors for species typing $[45,89,90]$, while the kDNA is the main target used for diagnostic screening [79, 91-93].

The kDNA is largely elected for DNA amplification of L. donovani complex, because of the high number of copies $(10,000)$ per parasite [94]. This target has been chosen for several applications, like for epidemiological studies in canine populations, took place in countries like Brazil and China [43, 95, 96], for species characterization $[43,97]$, for treatment follow-up and for assays development, with great results [72, 98].

Rocha et al. [99] compared different PCR protocols for Leishmania subgenus species detection, based on kDNA minicircle or mini-exon amplification. Concerning the kDNA minicircle, as long as the PCR protocol for L. amazonensis pointed out no specificity, since L. infantum was also detected, the PCR assay for L. infantum did not amplify DNA of any Viannia spp. or L. amazonensis, showing thus the importance also in selecting a specific and representative region of the target DNA, for primers design or selection from other authors. The mini-exon protocol presented inability to recognize any Leishmania subgenus species. Intraspecific variations of the utilized strains were considered to explain it. Roelfsema et al. [42] have compared the mini-exon and the Internal Transcribed Spacer1 (ITS-1) rDNA in molecular typing of clinical samples. The mini-exon has performed better for typing species belonging to L. Viannia subgenus by sequencing, whereas 
Table 2 Advantages and limitations of molecular methods used in leishmaniases diagnosis

\begin{tabular}{|c|c|c|}
\hline Method & Advantage & Limitation \\
\hline Conventional PCR (CPCR) & $\begin{array}{l}\text { High sensitivity, specificity and accurate results. } \\
\text { Many applications in molecular analysis. Easy } \\
\text { diagnostic interpretation. }\end{array}$ & $\begin{array}{l}\text { Unable to quantify the target DNA. Qualitative } \\
\text { test. Time consuming. Limited detection } \\
\text { range of some assays. }\end{array}$ \\
\hline Quantitative real-time PCR (qPCR) & $\begin{array}{l}\text { Higher sensitivity, specificity and security, } \\
\text { quantitative capacity and speedy results. } \\
\text { Possibility of species differentiation by melting } \\
\text { temperature. }\end{array}$ & $\begin{array}{l}\text { High cost due to equipment (thermocycler). } \\
\text { Difficulty in interpreting the results, needing } \\
\text { thus of a well-trained operator. }\end{array}$ \\
\hline Nested-PCR (nPCR) & $\begin{array}{l}\text { Higher specificity and sensitivity. Useful } \\
\text { technique for studying the molecular } \\
\text { epidemiology in the field. }\end{array}$ & $\begin{array}{l}\text { Time consuming and higher cost. Unable to } \\
\text { quantify the target DNA. Qualitative test. }\end{array}$ \\
\hline $\begin{array}{l}\text { Quantitative Nucleic Acid } \\
\text { Sequence-Based Assay (QT-NASBA) }\end{array}$ & $\begin{array}{l}\text { High specificity. It is based on an isothermal } \\
\text { reaction and thus overcomes the need for a } \\
\text { thermocycler; Ideal for lower-tech laboratories. } \\
\text { Quantitative capacity. Indicated to detect active } \\
\text { diseases; RNA detection. }\end{array}$ & $\begin{array}{l}\text { It uses electrochemiluminescence as tool of } \\
\text { detection, which involves more handling } \\
\text { steps and procedure time. Assays developed } \\
\text { only for RNA detection. . Few studies yet. }\end{array}$ \\
\hline $\begin{array}{l}\text { NASBA coupled with oligochromatography } \\
\text { (NASBA-OC) }\end{array}$ & $\begin{array}{l}\text { High specificity. Speedy results. There is no } \\
\text { need of complex laboratorial structure. Simple } \\
\text { dipstick format for the detection of } \\
\text { amplification products. RNA detection. }\end{array}$ & $\begin{array}{l}\text { Unable to quantify the target RNA. Assays } \\
\text { developed only for RNA detection. Few } \\
\text { studies yet. }\end{array}$ \\
\hline $\begin{array}{l}\text { Loop-Mediated Isothermal Amplification } \\
\text { (LAMP) }\end{array}$ & $\begin{array}{l}\text { High sensitivity. Low cost. Isothermal reaction, } \\
\text { there is no need for a thermocycler. The } \\
\text { temperature stability of the reagents enables its } \\
\text { use in field conditions. }\end{array}$ & $\begin{array}{l}\text { Unable to quantify the target DNA. Qualitative } \\
\text { test. Few studies yet. }\end{array}$ \\
\hline
\end{tabular}

ITS-1 PCR has differentiated L. infantum and L. donovani after a Hae III RFLP analysis.

As kDNA, the ribosomal RNA small subunit gene (SSU rRNA), as well as the ITS-1 region have been explored for many objectives, including epidemiological researches in human and canine populations [40, 97, 100], assays optimization [35, 47, 70] and for studies involving HIV/VL co-infected patients, a situation in which the serological diagnosis of VL is limited, and the molecular diagnosis is highlighted [101, 102]. A qPCR system for CL created by Paiva-Cavalcanti et al. [82] using kDNA as target has applicability in population studies, etiological diagnosis and the monitoring of treatment efficacy of individual patients. The same work demonstrated the high concordance between kDNA and SSU rDNA, concluding that both may be used for American CL diagnosis;

Table 3 Clinical sensitivity and specificity of different immunological and molecular methods for diagnosis of leishmaniases

\begin{tabular}{|c|c|c|c|c|c|}
\hline Method/clinical form & Specimen & Antigen/target & Sensitivity (\%) & Specificity (\%) & Reference (s) \\
\hline \multicolumn{6}{|l|}{ Immunological tests: } \\
\hline ELISANL & Human serum & rK39 & 96 & 100 & {$[19]$} \\
\hline TRALd/NL & Human serum & rK39, K26 & 100 & 98 & {$[24]$} \\
\hline FC-ALPA/CL & Human serum & Live L. braziliensis promastigotes & $85.7-97.9$ & 76.0-93.7 & {$[29]$} \\
\hline FC-ALPA-lgG/CL & Human serum & Live L. braziliensis promastigotes & 86 & 78 & {$[30]$} \\
\hline FC-AFPA-IgG/CL & Human serum & Fixed L. braziliensis promastigotes & 90 & 78 & {$[30]$} \\
\hline \multicolumn{6}{|l|}{ Molecular tests: } \\
\hline CPCR/VL & Human blood & ITS-1, kDNA minicircle & $53.7-97.78$ & $61.82-100$ & {$[41,51]$} \\
\hline CPCR/NL & Canine blood & ITS-1, kDNA minicircle & 72.2-98.7 & $83.3-96.4$ & {$[41,43,50]$} \\
\hline qPCR/VL & Human blood & ITS-1, kDNA minicircle & $91.3-100$ & $29.6-100$ & {$[41,51]$} \\
\hline NASBA-OCNL & Human blood & $18 \mathrm{~S}$ RNA; $18 \mathrm{~S}$ DNA & 79.8-93.3 & 100 & {$[66,67]$} \\
\hline LAMP/VL & Human blood & kDNA minicircle & 96.4 & 98.5 & {$[72]$} \\
\hline LAMP/PKDL & Human tissue biopsy & kDNA minicircle & 96.8 & 98.5 & {$[72]$} \\
\hline LAMP/NL & Canine blood & cysteine Protease B (cpb) & $38.2-69.5$ & $65.2-89.5$ & {$[73]$} \\
\hline
\end{tabular}


altogether, the results indicate the best performance of the kDNA protocol. Summarizing, the kDNA target may be used for diagnosis due to its sensitivity $[78,79,87,103-$ 105], whereas ITS-1 is more specific and may be used for species identification [78].

Regarding the advances in molecular biology, the choice of the target region to be imaged is the key point for the successful use of diagnostic PCR-based technologies.

\section{Proposal of gold-standard diagnostic strategies for leishmnaniases detection in humans}

Technological advances have contributed to raise new diagnostic guidelines not only in the parasitological field, but also in all areas regarding pathology. The technology has brought new analytical possibilities, with increasingly speed, accuracy and reliability. In microbiology, roboticbased equipments are helping to provide molecular assessments with safety and precision in both diagnostic routine and research. Regarding the leishmaniases, the advent of real-time PCR thermocyclers and flow-cytometric analysis (mainly) has contributed to the development of sensitive and specific approaches which have especially contributed to solve inconclusive cases, thus enabling implementation of early and adequate treatment. The establishment of a gold-standard immunological or molecular diagnosis is still a challenge, mainly because of a lack of standardization among laboratories and also structural/ economic concerns. In fact, the complexity of leishmaniases also acts as an important barrier to be surpassed. Therefore, we propose a combination of different techniques for maximizing sensitivity and specificity, for a safe and reliable diagnosis: for $\mathrm{CL}$, when MST is positive and parasitological analysis is negative (or is not performed), qPCR and/or FC could be employed as complementary investigation. For VL, when clinical evaluation is indicative (after differential diagnoses) and screening serological tests show negative results, qPCR could be employed as an alternative exam performed in reference centers, thus avoiding the painful and invasive bone marrow biopsy, especially for children. For immunosuppressed individuals such as HIV/VL co-infected patients, the monitoring of parasite load through qPCR is fundamental to predict relapses as well as treatment failures.

\section{Conclusions}

Immunological tools are options in leishmaniases diagnosis, highlighting the growth of FC as a more specific and sensitive alternative to overcome the limitations of these techniques and even as a method to assess clinical cure. Likewise, molecular diagnosis has become a potential strategy to provide the early detection and consequently the fast treatment implementation, as well as for species characterization, assessment of treatment efficacy and monitoring of relapses. The easiness, safety and high accuracy have made the molecular biology increasingly interesting as complement or as alternative for defining the definitive VL and CL diagnosis. The technological advance in this case has becoming an adjuvant to prevent the continuous spread of the disease and its social consequences, mainly at poor populations.

\section{Competing interests}

The authors certify that there are no competing interests with any financial organization regarding the material discussed in the manuscript.

\section{Authors' contributions}

MPC and VRAP contributed equally to the intellectual construction, writing and editing of the article. RCSM, RPS, LAMTS and SCGA contributed with research, analysis and interpretation of data regarding molecular tools. DHCT, MCABC and RFS contributed with research, analysis and interpretation of data regarding immunological tools. All authors read and approved the final version of this manuscript.

\section{Author details}

'Department of Immunology, Aggeu Magalhães Research Center, Oswaldo Cruz Foundation, Av. Prof. Moraes Rego s / n, 50670-420 Recife, PE, Brazil. ${ }^{2}$ Department of Natural and Exact Sciences, University of Pernambuco (UPE), St. Capitão Pedro Rodrigues, 105, 55920-000 São José, Garanhuns, PE, Brazil.

Received: 16 March 2015 Accepted: 5 June 2015

Published online: 17 June 2015

\section{References}

1. Ashford RW. The leishmaniases as emerging and reemerging zoonoses. Int J Parasitol. 2000;30:1269-81.

2. Herwaldt BL. Leishmaniasis. Lancet. 1999;354:1191-99.

3. Alvar J, Vélez ID, Bern C, Herrero M, Desjeux P, Cano J, et al. Leishmaniasis worldwide and global estimates of its incidence. PLOS ONE. 2012:7(5):e35671.

4. Desjeux P. Public health aspects and control. Clin Dermatol. 1996;14:417-23.

5. Hotez PJ, Molyneux DH, Fenwick A, Ottesen E, Sachs SE, Sachs DJ. Incorporating a rapid-impact package for neglected tropical diseases with programs for HIV/AIDS, tuberculosis, and malaria. PLoS Med. 2006;3:e102.

6. Hotez PJ, Remme JH, Buss P, Alleyne G, Morel C, Breman JG. Combating tropical infectious diseases: report of the disease control priorities in developing countries project. Clin Infect Dis. 2004:38:871-8.

7. BRASIL. Secretaria de Vigilância em Saúde. Departamento de Vigilância Epidemiológica. Manual de Vigilância e Controle da Leishmaniose Visceral. 1st ed. Brasília-DF: Ministério da Saúde; 2014

8. Souza AP, Soto M, Costa JML, Boaventura VS, de Oliveira Cl, et al. Towards a more precise serological diagnosis of human tegumentary leishmaniasis using Leishmania recombinant proteins. PLoS ONE. 2013;8(6):e66110.

9. Romero HD, Silva LA, Silva-Vergara ML, Rodrigues V, Costa RT, Guimarães SF, et al. Comparative study of serologic tests for the diagnosis of asymptomatic visceral leishmaniasis in an endemic area. Am J Trop Med Hyg. 2009;81(1):27-33.

10. Silveira JF, Umezawa ES, Luquetti AO. Chagas disease: recombinant Trypanosoma cruzi antigens for serological diagnosis. Trends in Parasitol. 2001;17:6.

11. Srivastava P, Gidwani K, Picado A, Van der Auwera G, Tiwary P, Ostyn B, et al. Molecular and serological markers of Leishmania donovani infection in healthy individuals from endemic areas of Bihar. India Trop Med Int Health. 2013;18(5):548-54.

12. Paiva-Cavalcanti M, Silva PS, de Brito MEF, Brandão-Filho SP. Gestão de Qualidade: Implementação do Serviço de Referência em Leishmanioses de Pernambuco-Brasil. Rev Patol Trop. 2010;39:151-6.

13. Alves CF, Alves CF, Figueiredo MM, Souza CC, Machado-Coelho GLL, Melo $\mathrm{MN}$, et al. American tegumentary leishmaniasis: effectiveness of an immunohistochemical protocol for the detection of Leishmania in Skin. PLOS ONE. 2013;8(5):e63343.

14. BRASIL. Secretaria de vigilância em saúde. Departamento de Vigilância Epidemiológica. Manual de Vigilância da Leishmaniose Tegumentar Americana. 2nd ed. Brasília-DF: Ministério da Saúde; 2007. 
15. Brito ME, Mendonça MG, Gomes YM, Jardim ML, Abath FG. Identification of potentially diagnostic Leishmania braziliensis antigens in human cutaneous leishmaniasis by immunoblot analysis. Clin Diagn Lab Immunol. 2000;7(2):318-21.

16. Brito ME, Mendonça MG, Gomes YM, Jardim ML, Abath FG. Dynamics of the antibody response in patients with therapeutic or spontaneous cure of American cutaneous leishmaniasis. T Roy Soc Trop Med H. 2001;95:203-6.

17. Szargiki R, Castro EA, Luz E, Kowalthuk W, Machado AM, Thomaz-Soccol V. Comparison of serological and parasitological methods for cutaneous leishmaniasis diagnosis in the State of Paraná, Brazil. Braz J Infect Dis. 2009;13(1):47-52.

18. Kumar D, Khanal B, Tiwary P, Mudavath SL, Tiwary NK, Singh R, et al. A comparative evaluation of blood versus serum samples in rapid immunochromatographic tests for visceral leishmaniasis. J Clin Microbiol. 2013;51(12):3955-9.

19. Palatnik-de-Sousa CB, Gomes EM, Paraguai-de-Souza E, Palatnik M, Luz K, Borojevic R. Leishmania donovani: titration of antibodies to the fucosemannose ligand as an aid in diagnosis and prognosis of visceral leishmaniasis. Trans R Soc Trop Med Hyg. 1995;89:390-3.

20. Carvalho FAA, Charest H, Tavares CAP, Matlashewski G, Valente EP, Rabello A, et al. Diagnosis of American visceral leishmaniasis in humans and dogs using the recombinant Leishmania donovani A2 antigen. Diagn Micr Infec Dis. 2002;43:289-95.

21. Gomes YM, Paiva-Cavalcanti M, Lira RA, Abath FGC, Alves LC. Diagnosis of canine visceral leishmaniasis: biotechnological advances. Vet J. 2008;175:45-52.

22. Assis TSM, Braga ASC, Pedras MJ, Barral AMP, Siqueira IC, Costa CHN, et al. Validação do teste imunocromatográfico rápido IT-LEISH ${ }^{\circledR}$ para o diagnóstico da leishmaniose visceral humana. Epidemiol serv saúde. 2008;17:107-16.

23. Oliveira GG, Magalhães FB, Teixeira MC, Pereira AM, Pinheiro CG, Santos LR, et al. Characterization of novel Leishmania infantum recombinant proteins encoded by genes from five families with distinct capacities for serodiagnosis of canine and human visceral leishmaniasis. Am J Trop Med Hyg. 2011;85:1025-34.

24. Nakatani M, Miranda-Badaró $R$, Meireles A, Trigo J, Netto EM, Badaró R. Avaliação da sensibilidade do teste rápido (TRALd) para detecção de anticorpos anti-Leishmania com o novo antígeno k26 adicionado ao k39. Rev Bras Med Trop. 2001; Supl 10.

25. Carvalho-Neta AV, Rocha RDR, Gontijo CMF, Reis AB, Martins-Filho OA. Citometria de fluxo no diagnóstico da leishmaniose visceral canina. Arq Bras Med Vet Zoo. 2006;58(4):480-8.

26. Ker HG, Coura-Vital W, Aguiar-Soares RD, Roatt BM, Moreira ND, Carneiro $\mathrm{CM}$, et al. Evaluation of a prototype flow cytometry test for serodiagnosis of canine visceral leishmaniasis. Clin Vaccine Immunol. 2013;20(12):1792-8.

27. Sousa S, Cardoso L, Reed SG, Reis AB, Martins-Filho OA, Silvestre R, et al. Development of a fluorescent based immunosensor for the serodiagnosis of canine leishmaniasis combining immunomagnetic separation and flow cytometry. PLoS Negl Trop Dis. 2013;7(8):2371.

28. Lemos EM, Gomes IT, Carvalho SFG, Rocha RDR, Pissinate JF, Martins-Filho $\mathrm{OA}$, et al. Detection of anti-Leishmania (Leishmania) chagasi immunoglobulin $\mathrm{G}$ by flow cytometry for cure assessment following chemotherapeutic treatment of American visceral leishmaniasis. Clin Vaccine Immunol. 2007;5:569-76.

29. Rocha RD, Gontijo CM, Elói-Santos SM, Teixeira-Carvalho A, Corrêa-Oliveira R, Ferrari TC, et al. Clinical value of anti-live Leishmania (Viannia) braziliensis immunoglobulin $\mathrm{G}$ subclasses, detected by flow cytometry, for diagnosing active localized cutaneous leishmaniasis. Trop Med Int Health. 2006;11(2):156-66.

30. Pereira VR, Reis LC, Souza MA, de Oliveira AP, de Brito ME, Lage PS, et al. Evaluation of anti-lived and anti-fixed Leishmania (Viannia) braziliensis promastigote lgG antibodies detected by flow cytometry for diagnosis and post-therapeutic cure assessment in localized cutaneous leishmaniasis. Diagn Microbiol Infect Dis. 2012;74(3):292-8.

31. Pissinate JF, Gomes IT, Peruhype-Magalhães V, Dietze R, Martins-Filho OA, Lemos EM. Upgrading the flow-cytometric analysis of anti-Leishmania immunoglobulins for the diagnosis of American tegumentary leishmaniasis. J Immunol Methods. 2008:336:193-202.

32. Oliveira AP, de Castro MC, de Almeida AF, de Souza MA, de Oliveira BC, Reis LC, et al. Comparison of flow cytometry and indirect immunofluorescence assay in the diagnosis and cure criterion after therapy of American tegumentary leishmaniasis by anti-live Leishmania (Viannia) braziliensis immunoglobulin G. J Immunol Methods. 2013;387(1-2):245-53.
33. Moore J, Roederer M. The flow cytometry shared resource laboratory: best practices to assure a high-quality, cost-effective partnership with biomedical research laboratories. Cytometry A. 2009;75:643-49.

34. Monti F, Rosetti M, Masperi P, Tommasini N, Dorizzi RM. Shared resource laboratories: impact of new design criteria to consolidate flow cytometry diagnostic service. Int J Lab Hematol. 2012;34:533-40.

35. Silva LA, Romero HD, Fagundes A, Nehme N, Fernandes O, Rodrigues V, et al. Use of the polymerase chain reaction for the diagnosis of asymptomatic Leishmania infection in a visceral leishmaniasis-endemic area. Rev Inst Med Trop São Paulo. 2013;55(2):101-4.

36. Reis LES, Coura-Vital W, Roatt BM, Bouillet LEM, Ker HG, Brito RCF, et al. Molecular diagnosis of canine visceral leishmaniasis: a comparative study of three methods using skin and spleen from dogs with natural Leishmania infantum infection. Vet Parasitol. 2013;197:498-503.

37. Paiva-Cavalcanti M, Brito MEF, Souza WV, Gomes YM, Abath FGC. The development of a real-time PCR assay for the quantification of Leishmania infantum DNA in canine blood. Vet J. 2009;182:356-8.

38. Pourabbas B, Ghadimi MA, Pouladfar G, Rezaee Z, Alborzi A. Quantification of Leishmania infantum kinetoplast DNA for monitoring the response to meglumine antimoniate therapy in visceral leishmaniasis. Am J Trop Med Hyg. 2013;88(5):868-71.

39. de Almeida Ferreira SA, Leite RS, Ituassu LT, Almeida GG, Souza DM, Fujiwara RT, et al. Canine skin and conjunctival swab samples for the detection and quantification of Leishmania infantum DNA in an Endemic Urban Area in Brazil. Plos Negl Trop Dis. 2012;6(4):e1596.

40. Santos-Marques LHS, Gomes LI, da Rocha ICM, da Silva TAM, Oliveira E, Morais MHF. Low parasite load estimated by QPCR in a cohort of children living in urban area endemic for visceral leishmaniasis in Brazil. Plos Negl Trop Dis. 2012;6(12):e1955.

41. Mohammadiha A, Mohebali M, Haghighi A, Mahdian R, Abadi AR, Zarei Z, et al. Comparison of real-time PCR and conventional PCR with two DNA targets for detection of Leishmania (Leishmania) infantum infection in human and dog blood samples. Exp Parasitol. 2013;133:89-94.

42. Roelfsema JH, Nozari N, Herremans T, Kortbeek LM, Pinelli E. Evaluation and improvement of two PCR targets in molecular typing of clinical samples of Leishmania patients. Exp Parasitol. 2011;127:36-41.

43. Wang JY, Ha Y, Gao CH, Wang Y, Yang YT, Chen HT. The prevalence of canine Leishmania infantum infection in western China detected by PCR and serological tests. Paras Vectors. 2011:4:69-76.

44. Maia C, Gomes J, Cristóvão J, Nunes M, Martins A, Rebêlo E, et al. Feline Leishmania infection in a canine leishmaniasis endemic region, Portugal. Vet Parasitol. 2010;174:336-40.

45. Fraga TL, Brustoloni YM, Lima RB, Dorval MEC, Oshiro EL, Oliveira J, et al. Polymerase chain reaction of peripheral blood as a tool for the diagnosis of visceral leishmaniasis in children. Mem Inst Oswaldo Cruz. 2010;105(3):310-13.

46. Cruz I, Millet A, Carrillo E, Chenik M, Salotra P, Verma S, et al. An approach for interlaboratory comparison of conventional and real-time PCR assays for diagnosis of human leishmaniasis. Exp Parasitol. 2013;134:281-89.

47. Ozensoy Toz S, Culha G, Yildiz ZF, Ertabaklar H, Alkan MZ, Vardarlı AT, et al. A real-time ITS1-PCR based method in the diagnosis and species identification of Leishmania parasite from human and dog clinical samples in Turkey. PLoS Neglected Trop Dis. 2013;7(5):e2205.

48. Khanra S, Datta S, Mondal D, Saha P, Bandopadhyay SK, Roy S, et al. RFLPS of ITS, ITS1 and hsp70 amplicons and sequencing of ITS1 of recent clinical isolates of Kala-azar from India and Bangladesh confirms the association of L. tropica with the disease. Acta Trop. 2012;124:229-34.

49. Grimaldi GJ, Tesh RB. Leishmaniases of the new world: current concepts and implications for future research. Clin Microbiol Rev. 1993;6:230-50.

50. Mohammadiha A, Haghighi A, Mohebali M, Mahdian R, Abadi AR, Zarei Z, et al. Canine visceral leishmaniasis: a comparative study of real-time PCR, conventional PCR, and direct agglutination on sera for the detection of Leishmania infantum infection. Vet Parasitol. 2013;192:83-90.

51. Junior MSCL, Zorzenon DCR, Dorval MEC, Pontes ERJC, Oshiro ET, Cunha R, et al. Sensitivity of PCR and real-time PCR for the diagnosis of human visceral leishmaniasis using peripheral blood. Asian Pac J Trop Dis. 2013;3(1):10-5

52. Solcà MS, Guedes CES, Nascimento EG, Oliveira GGS, Santos WLC, Fraga DBM, et al. Qualitative and quantitative polymerase chain reaction (PCR) for detection of Leishmania in spleen samples from naturally infected dogs. Vet Parasitol. 2012;184:133-40. 
53. Pandey K, Pandey BD, Mallik AK, Kaneko O, Uemura H, Kanbara H. Diagnosis of visceral leishmaniasis by polymerase chain reaction of DNA extracted from Giemsa's solution-stained slides. Parasitol Res. 2010;107:727-30.

54. Silva RN, Amorim AC, Brandão RMSS, de Andrade HM, Yokoo LM, Ribeiro $\mathrm{ML}$, et al. Real-time PCR in clinical practice: a powerful tool for evaluating Leishmania chagasi loads in naturally infected dogs. Ann Trop Med Parasitol. 2010;104(2):137-43.

55. Fisa R, Riera C, López-Chejade P, Molina I, Gállego M, Falcó V, et al. Leishmania infantum DNA detection in urine from patients with visceral leishmaniasis and after treatment control. Am J Trop Med Hyg. 2008;78(5):741-44.

56. Vaish M, Mehrotra S, Chakravarty J, Sundar S. Noninvasive molecular diagnosis of human visceral leishmaniasis. J Clin Microbiol. 2011;49(5):2003-5.

57. Almeida ABPF, Sousa VRF, Gasparetto ND, da Silva GFR, Figueiredo FB, Dutra $V$, et al. Canine visceral leishmaniasis: diagnostic approaches based on polymerase chain reaction employing different biological samples. Diagn Microbiol Infect Dis. 2013;76:321-4

58. Leite RS, de Almeida FS, Ituassu LT, Melo MN, Andrade ASR. PCR diagnosis of visceral leishmaniasis in asymptomatic dogs using conjunctival swab samples. Vet Parasitol. 2010;170:201-6.

59. Leite RS, Mendes VC, Ferreira ALC, Andrade ASR. The use of conjunctival swab samples for PCR screening for visceral leishmaniasis in vaccinated dogs. Rev Bras Parasitol Vet. 2011;20(1):36-41.

60. Solano-Gallego L, Rodriguez-Cortes A, Trotta M, Zampieron C, Razia L, Furlanello T, et al. Detection of Leishmania infantum DNA by fret-based real-time $P C R$ in urine from dogs with natural clinical leishmaniosis. Vet Parasitol. 2007;147:315-9.

61. Gonçalves SC, Régis-da-Silva CG, Brito MEF, Brandão-Filho SP, Paiva-Cavalcanti M. Application of the mammalian glyceraldehyde-3-phosphate dehydrogenase gene for sample quality control in multiplex PCR for diagnosis of leishmaniasis. J Venom Anim Toxins Ind Trop Dis. 2012;2:188-97.

62. Yang S, Rothman R. PCR-based diagnostics for infectious diseases: uses, limitations and future applications in acute-care settings. Lancet. 2004;4:337-48.

63. Andreadou M, Liandris E, Kasampalidis IN, Taka S, Antoniou M, Ntais P, et al. Evaluation of the performance of selected in-house and commercially available PCR and real-time PCR assays for the detection of Leishmania DNA in canine clinical samples. Exp Parasitol. 2012;131:419-24.

64. Gonçalves-de-Albuquerque SC, Pessoa-e-Silva R, Morais RCS, Trajano-Silva LAM, Régis-da-Silva CG, Brandão-Filho SP, et al. Tracking false-negative results in molecular diagnosis: proposal of a triplex-PCR based method for leishmaniasis diagnosis. J Venom Anim Toxins Incl Trop Dis. 2014;20:16.

65. Vries PJ, van der Meide WF, Godfried MH, Schallig HDFH, Dinant HJ, Faber WR. Quantification of the response to miltefosine treatment for visceral leishmaniasis by QT-NASBA. Trans R Soc Trop Med Hyg. 2006;100:1183-6.

66. Basiye FL, Mbuchi M, Magiri C, Kirigi G, Deborggraeve S, Schoone GJ, et al. Sensitivity and specificity of the Leishmania OligoC-TesT and NASBA-oligochromatography for diagnosis of visceral leishmaniasis in Kenya. Trop Med Int Health. 2010;15(7):806-10.

67. Mugasa CM, Laurent T, Schoone GJ, Basiye FL, Saad AA, el Safi S, et al. Simplified molecular detection of Leishmania parasites in various clinical samples from patients with leishmaniasis. Paras Vectors. 2010:3:13-8.

68. Mugasa CM, Deborggraeve S, Schoone GJ, Laurent T, Leeflang MM, Ekangu RA, et al. Accordance and concordance of PCR and NASBA followed by oligochromatography for the molecular diagnosis of Trypanosoma brucei and Leishmania. Trop Med Int Health. 2010;15(7):800-5.

69. Van der Meide W, Guerra J, Schoone G, Farenhorst M, Coelho L, Faber W, et al. Comparison between quantitative nucleic acid sequence-based amplification, real-time reverse transcriptase PCR, and real-time PCR for quantification of Leishmania parasites. J Clin Microbiol. 2008;46(2):73-8.

70. Khan MGM, Bhaskar KRH, Salam MA, Akther T, Pluschke G, Mondal D. Diagnostic accuracy of loop-mediated isothermal amplification (LAMP) for detection of Leishmania DNA in buffy coat from visceral leishmaniasis patients. Paras vectors. 2012;5:280-7.

71. Thekisoe OMM, Bazie RSB, Coronel-Servian AM, Sugimoto C, Kawazu S, Inoue N. Stability of Loop-Mediated Isothermal Amplification (LAMP) reagents and its amplification efficiency on crude trypanosome DNA templates. J Vet Med Sci. 2009;71(4):471-5.

72. Verma S, Avishek K, Sharma V, Negi NS, Ramesh V, Salotra P. Application of loop-mediated isothermal amplification assay for the sensitive and rapid diagnosis of visceral leishmaniasis and post-kala-azar dermal leishmaniasis. Diagn Microbiol Infect Dis. 2013;75:390-5.
73. Chaouch M, Mhadhbi M, Adams ER, Schoone GJ, Limam S, Gharbi Z, et al. Development and evaluation of a loop-mediated isothermal amplification assay for rapid detection of Leishmania infantumin canine leishmaniasis based on cysteine protease B genes. Vet Parasitol. 2013;198(1-2):78-84.

74. Azzi K, Soltani A, Alipour H. Molecular detection of Leishmania isolated from Cutaneous leishmaniasis patients in Jask County, Hormozgan Province, Southern Iran. Asian Pac J Trop Med. 2012;5(7):514-7.

75. Mohaghegh MA, Fata A, Salehi GH, Berenji F, Mousavi bazzaz M, Rafatpanah $\mathrm{H}$, et al. Molecular identification of Leishmania species using samples obtained from negative stained smears. Iranian J Parasitol. 2013;8(2):337-41.

76. Shahbazi F, Shahabi S, Kazemi B, Mohebali M, Abadi AR, Zare Z. Evaluation of PCR assay in diagnosis and identification of cutaneous leishmaniasis: a comparison with the parasitological methods. Parasitol Res. 2008;103:1159-62

77. Neitzke-Abreu HC, Venazzi MS, Bernal MVZ, Reinhold-Castro KR, Vagetti F, Mota CA, et al. Detection of DNA from Leishmania (Viannia): accuracy of polymerase chain reaction for the diagnosis of cutaneous leishmaniasis. PLOS One. 2013;8(7):e62473.

78. El-Beshbishy HA, Al-Ali KH, El-Badry AA. Molecular characterization of cutaneous leishmaniasis in Al-Madinah Al-Munawarah province, western Saudi Arabia. Int J Infect Dis. 2013;17:e334-8.

79. Yehia L, Adib-Houreih M, Raslan WF, Kibbi AG, Loya A, Firooz A, et al. Molecular diagnosis of cutaneous leishmaniasis and species identification: analysis of 122 biopsies with varied parasite index. J Cutan Pathol. 2012;39:347-55

80. Francino O, Altet L, Sanchez-Robert E, Rodriguez A, Solano-Gallego L, Alberola J. Advantages of real-time PCR assay for diagnosis and monitoring of canine leishmaniosis. Vet Parasitol. 2006;137:214-21.

81. Weiranther $\mathrm{L}$, Jeronimo SMB, Gautam S, Sundar S, Kang M, Kurtz MA, et al. Serial quantitative PCR assay for detection, species discrimination, and quantification of Leishmania spp. in human samples. J Clin Microbiol. 2011;49:3892-904.

82. Paiva-Cavalcanti M, Dantas-Torres F, Albuquerque SCG, Morais RCS, Brito MEF, Otranto D, et al. Quantitative real time PCR assays for the detection of Leishmania (Viannia) braziliensis in animals and humans. Mol Cell Probes. 2013;27:122-8

83. Pita-Pereira D, Lins R, Oliveira MP, Lima RB, Pereira BAS, Moreira OC, et al. SYBR green-based real-time PCR targeting kinetoplast DNA can be used to discriminate between the main etiologic agents of Brazilian cutaneous and visceral leishmaniasis. Paras Vectors. 2012;12:5-15.

84. Shirian S, Oryan A, Hatam GR, Daneshbod K, Daneshbod Y. Molecular diagnosis and species identification on mucosal leishmaniasis in Iran and correlation with cytological findins. Acta Trop. 2012;56:304-9.

85. Reithinger R, Dujardin JC, Louzir H, Pirmez C, Alexander B, Brooker S. Cutaneous leishmaniasis. Lancet Infect Dis. 2007;7(9):581-96.

86. Masmoudí A, Hariz W, Marrekchi S, Amouri M, Turki H. Old World cutaneous leishmaniasis: diagnosis and treatment. J Dermatol Case Rep. 2013;2:31-41.

87. Bensoussan E, Nesereddin A, Jonas F, Schnur LF, Jaffe CL. Comparison of PCR assays for diagnosis of cutaneous leishmaniasis. J Clin Microbiol. 2006:44(4):1435-9.

88. Khosravi S, Hejazi SH, Hashemzadeh M, Eslami G, Darani HY. Molecular diagnosis of Old World leishmaniasis: real-time PCR based on tryparedoxin peroxidase gene for the detection and identification of Leishmania spp. J Vector Borne Dis. 2012;49:15-8.

89. Van der Auwera G, Maes I, Doncker S, Ravel C, Cnops L, Van Esbroeck M, et al. Heat-shock protein 70 gene sequencing for Leishmania species typing in European tropical infectious disease clinics. Euro Surveill. 2013;18(30):20543.

90. Graça GC, Volpini AC, Romero GAS, Oliveira-Neto MP, Hueb M, Parrozzi R, et al. Development and validation of PCR-based assays for diagnosis of American cutaneous leishmaniasis and identification of the parasite species. Mem Inst Oswaldo Cruz. 2012;107(5):664-74.

91. Brewster S, Aslett M, Barker DC. Kinetoplast DNA minicircle database. Parasitol Today. 1998;14:437-8.

92. Brewster S, Barker DC. Analysis of minicircle classes in Leishmania (Viannia) species. Trans R Soc Trop Med Hyg. 2002;96:55-63.

93. Lambson B, Barker DC. Homologous minicircles in Leishmania donovani. Trans R Soc Trop Med Hyg. 2002;96:75-80.

94. Rodgers MR, Popper SJ, Wirth DF. Amplification of Kinetoplast DNA as a tool in the detection and diagnosis of Leishmania. Exp Parasitol. 1990;71:267-75.

95. Bigeli JM, Júnior WPO, Teles NMM. Diagnosis of Leishmania (Leishmania) chagasi infection in dogs and the relationship with environmental and 
sanitary aspects in the municipality of Palmas, state of Tocantins, Brazil. Rev Soc Bras Med Trop. 2012;45(1):18-23.

96. Shang L, Peng W, Jin H, Xu D, Zhong N, Wang W, et al. The prevalence of canine Leishmania infantum infection in Sichuan Province, southwestern China detected by real time PCR. Paras Vectors. 2011;4:173-7.

97. Cruz I, Acosta L, Gutiérrez MN, Nieto J, Cañavate C, Deschutter J, et al. A canine leishmaniasis pilot survey in an emerging focus of visceral leishmaniasis: Posadas (Misiones, Argentina). BMC Infect Dis. 2010;10:342-9.

98. Verma S, Bhandari V, Avishek K, Ramesh V, Salotra P. Reliable diagnosis of post-kala-azar dermal leishmaniasis (PKDL) using slit aspirate specimen to avoid invasive sampling procedures. Trop Med Int Health. 2013;18(3):268-75.

99. Rocha MN, Margonari C, Presot IM, Soares RP. Evaluation of 4 polymerase chain reaction protocols for cultured Leishmania spp. typing. Diagn Microbiol Infect Dis. 2010;68:401-9.

100. Mondal D, Nasrin KN, Huda MM, Kabir M, Hossain MS, Kroeger A, et al. Enhanced case detection and improved diagnosis of PKDL in a kala-azarendemic area of Bangladesh. PLoS Negl Trop Dis. 2010;4(10):e832.

101. Cruz I, Caiiavate C, Rubio JM, Morales MA, Chicharro C, Laguna F, et al. A nested polymerase chain reaction ( $L n-P C R)$ for diagnosing and monitoring Leishmania infantum infection in patients co-infected with human immunodeficiency virus. Trans R Soc Trop Med Hyg. 2002;96:185-9.

102. Stenzinger A, Nemeth J, Klauschen F, Schewe C, Ladhoff AM, Muckenhuber A, et al. Visceral leishmaniasis in a patient with AIDS: early pathological diagnosis using conventional histology, PCR and electron microscopy is the key for adequate treatment. Virchows Arch. 2012;460:357-60.

103. Azmi K, Nasereddin A, Ereqat S, Schnur L, Schonian G, Abdeen Z. Methods incorporating a polymerase chain reaction and restriction fragment length polymorphism and their use as a 'gold standard' in diagnosing Old World cutaneous leishmaniasis. Diagn Microbiol Infect Dis. 2011;71:151-5.

104. Bhargava P, Singh R. Developments in diagnosis and antileishmanial drugs. Interdiscip Perspect Infect Dis. 2012;2012:626838.

105. Silva JGL, Silva TM, Peloso EF, Machado-Coelho GLL, Mayrink W, Ariosa MCF, et al. Comparison among three polymerase chain reaction assays on detection of DNA from Leishmania in biological samples from patients with American cutaneous leishmaniasis. Rev Soc Bras Med Trop. 2012;45(2):257-9.

\section{Submit your next manuscript to BioMed Central and take full advantage of:}

- Convenient online submission

- Thorough peer review

- No space constraints or color figure charges

- Immediate publication on acceptance

- Inclusion in PubMed, CAS, Scopus and Google Scholar

- Research which is freely available for redistribution 